\title{
Average Metabolic Standard Uptake Value
}

National Cancer Institute

\section{Source}

National Cancer Institute. Average Metabolic Standard Uptake Value. NCI Thesaurus.

Code C96566.

A semiquantitative analysis of the average uptake of analyte by body tissue in relation to the total administered dose of the analyte. 